\title{
Correction to: NFATc2 is an intrinsic regulator of melanoma dedifferentiation
}

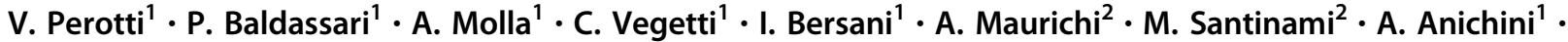 \\ R. Mortarini ${ }^{1}$
}

Published online: 28 January 2019

(c) The Author(s) 2019. This article is published with open access

\section{Correction to: Oncogene; \\ https://doi.org/10.1038/onc.2015.355; \\ Published online 21 Sept 2015}

In Fig. 6e, the authors noticed that wrong blots for MITF, MART-1 expression/modulation, and for $\beta$-actin were presented, due to the similarity with experiments shown in Figure 5c. Correct MITF, MART-1, and $\beta$-actin blots were added to the revised Fig. 6 shown in the associated Correction. The meaning of the results shown in Fig. 6e, as well as the conclusions of this paper were not affected, and the authors regret for this error. These errors have not been fixed in the original Article.
Open Access This article is licensed under a Creative Commons Attribution 4.0 International License, which permits use, sharing, adaptation, distribution and reproduction in any medium or format, as long as you give appropriate credit to the original author(s) and the source, provide a link to the Creative Commons license, and indicate if changes were made. The images or other third party material in this article are included in the article's Creative Commons license, unless indicated otherwise in a credit line to the material. If material is not included in the article's Creative Commons license and your intended use is not permitted by statutory regulation or exceeds the permitted use, you will need to obtain permission directly from the copyright holder. To view a copy of this license, visit http://creativecommons. org/licenses/by/4.0/.

These authors contributed equally: A Anichini, R Mortarini

The original article can be found online at https://doi.org/10.1038/onc. 2015.355

\section{R. Mortarini}

roberta.mortarini@istitutotumori.mi.it

1 Human Tumors Immunobiology Unit, Department of Experimental Oncology and Molecular Medicine, Fondazione IRCCS Istituto Nazionale dei Tumori, Milan, Italy

2 Melanoma and Sarcoma Unit, Department of Surgery, Fondazione IRCCS Istituto Nazionale dei Tumori, Milan, Italy 


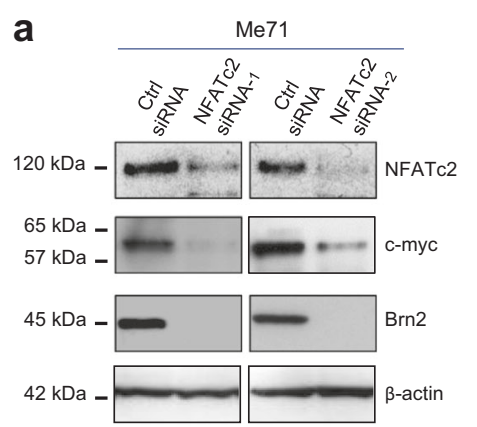

b
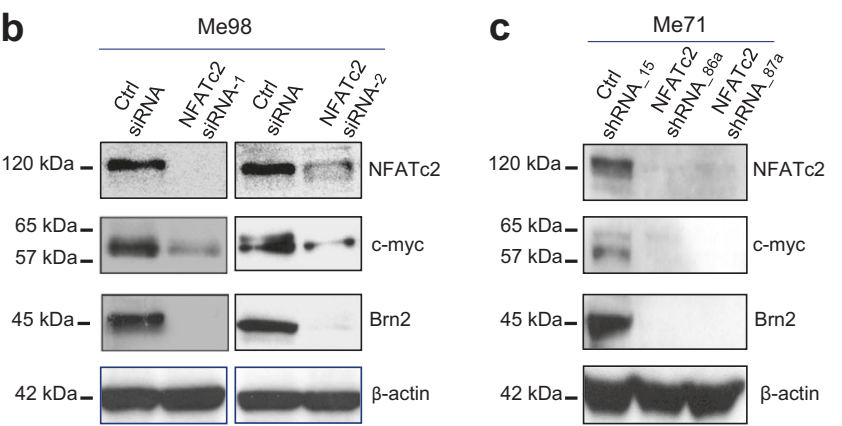

d

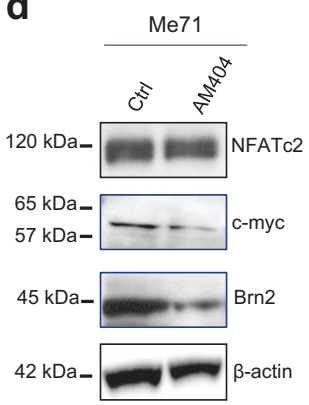

e

f

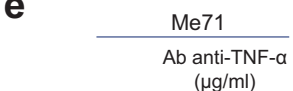

$(\mu \mathrm{g} / \mathrm{ml})$

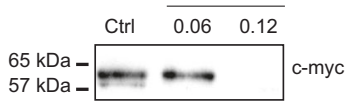

$56 \mathrm{ka}-\square=$
$52 \mathrm{kDa}-\square$

$18 \mathrm{kDa}-\mathrm{m}$ MART-1

$42 \mathrm{kDa}-\square \beta$-actin

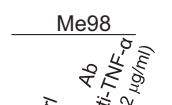

g

$65 \mathrm{kDa}$

$57 \mathrm{kDa}-10 \mathrm{c}-\mathrm{myc}$

$45 \mathrm{kDa}-\mathrm{Budin}$ Brn2

$56 \mathrm{kDa}-\longrightarrow$ MITF

$42 \mathrm{kDa}-\longrightarrow$-actin

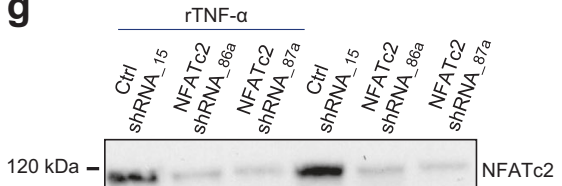

$120 \mathrm{kDa}-\ldots+\infty \quad$ NFATc2

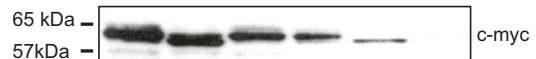

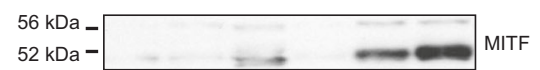

$52 \mathrm{kDa}-\mathrm{W}$

$18 \mathrm{kDa}-\mathrm{m}$ MART-1

$42 \mathrm{kDa}-\mathrm{B}$-actin h

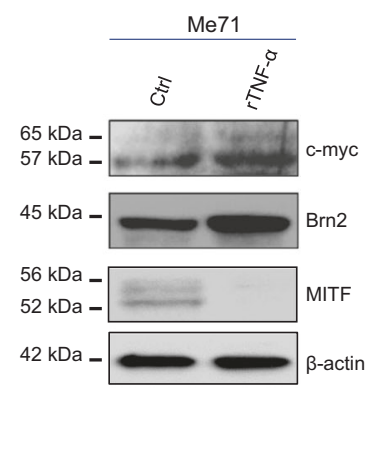

Fig. 6 